\title{
O PRINCÍPIO DA SOLIDARIEDADE E OS DIREITOS HUMANOS DE NATUREZA AMBIENTAL*
}

THE PRINCIPLE OF SOLIDARITY AND HUMAN RIGHTS TO ENVIRONMENTAL

\author{
Elza Antonia Pereira Cunha Boiteux ${ }^{* *}$
}

\begin{abstract}
Resumo:
1. O sistema jurídico e as questões ambientais. 2. O sistema piramidal e a nova temporalidade. 3. O sistema em rede. 4. O progresso científico e o meio ambiente. 5. A energia elétrica e a qualidadade de vida. 6. O princípio da solidariedade. 7. O dever de solidariedade.

Palavras-chave: Ética. Dever de solidariedade. Direitos humanos.

Abstract:

1. The legal system and environmental issues. 2. The pyramid system and the new perception of time. 3. The network system. 4. Scientific progress and the environment. 5. Eletric power and quality of life. 6. The principle of solidarity. 7. The duty of solidarity.
\end{abstract}

Keywords: Ethic. Solidarity obligation. Human rights.

1. O sistema jurídico e as questões ambientais

Os Direitos Humanos de natureza ambiental rompem com a visão individualista do Estado, pois não são passíveis de apropriação, nem de identificação a um titular. Esses direitos não eram protegidos pelo Estado porque não sendo de ninguém especificamente, eram do interesse de todos ou de um grupo considerável de pessoas. ${ }^{1}$

A exigência de determinação do titular do direito subjetivo não significa a sua necessária individuação, pois eles podem corresponder: a) a interesses difusos, pertencentes a pessoas não individuadas, mas ligadas por circunstâncias de fato; b) a interesses coletivos, de que são titulares grupos sociais determinados, mas despidos de personalidade jurídica.

Num primeiro momento, esses interesses visavam à proteção dos recursos naturais, tais como o ar, a água, o solo, a biosfera, etc. Num segundo momento, eles passaram a incluir bens culturais e históricos que estão entre os recursos ambientais, como os bens e interesses que sofrem a intervenção humana e que afetam a existência planetária.

Pesquisa realizada sob a Coordenação de Mario G. Losano com patrocínio do CNPq.

** Professora Doutora da Faculdade de Direito da Universidade de São Paulo.

1 SOARES, Guido Fernando Silva. Direito internacional do meio ambiente: emergência, obrigações e responsabilidades. São Paulo: Atlas, 2001. TRINDADE, Antonio Augusto Cançado. Direitos humanos e meio ambiente. Porto Alegre: Sergio Fabris, 1993. 
A consciência da limitação dos recursos naturais e da necessidade de utilização ordenada desses recursos levou a substituição do paradigma individualista, pelo paradigma da solidariedade, ${ }^{2}$ no qual os interesses mais relevantes são os da comunidade. Não só a degradação predadora dos recursos naturais, mas também a evolução e ampliação dos direitos humanos nos níveis nacional e internacional impuseram uma nova visão sobre responsabilidade social e deveres coletivos. ${ }^{3}$

AConferênciadas Nações Unidas sobreo Meio Ambienteeo Desenvolvimento de 1992, também denominada ECO-92, consignou vinte e sete princípios, tendo estes por finalidade estabelecer as bases para o desenvolvimento sustentável. ${ }^{4}$ Considerado o mais relevante dentre eles, o "Princípio da Precaução" foi aprovado nos seguintes termos:

Princípio 15 - De modo a proteger o meio ambiente, o princípio da precaução deve ser amplamente observado pelos Estados, de acordo com suas capacidades. Quando houver ameaça de danos sérios ou irreversíveis, a ausência de absoluta certeza científica não deve ser utilizada como razão para postergar medidas eficazes e economicamente viáveis para prevenir a degradação ambiental. ${ }^{5}$ (itálicos apostos)

A Declaração foi subscrita pelos representantes dos 174 países presentes; ${ }^{6}$ entre eles o então Ministro das Relações Exteriores, Professor Celso Lafer, representou o Brasil. Aprovada por unanimidade em Plenário, ela se aplica pelo que nela se contém. ${ }^{7}$

O princípio da precaução foi adotado em praticamente todos os tratados posteriores sobre meio ambiente, ${ }^{8}$ demonstrando que os riscos, as ameaças ou o perigo de

2 FARIAS, José Fernando de Castro. A origem do direito de solidariedade. Rio de Janeiro: Renovar, 1998. COMPARATO, Fábio Konder. A solidariedade. In: ÉTICA: direito, moral e religião no mundo moderno, São Paulo: Companhia das Letras, 2006. p. 577-581.

3 LAMBERT-FRAIVRE, Ivonne. L'éthique de la responsabilité. Revue Trimestrielle de Droit Civil, Paris, p. 1-22, 1998. JONAS, Hans. Ética, medicina e técnica. Lisboa: Passagens, 1994; O principio responsabilidade: ensaio de uma ética para a civilização tecnológica. Rio de Janeiro: Contraponto: Ed. Puc-Rio, 2006. p. 83-88.

4 Documento original "A/CONF.151/26 (Vol. I), Report of the United Nations Conference on Environment and Development". Disponível em: <www.un.org/documents/ga/conf151/aconf15126-1annex 1.htm>.

5 Utilizamos a tradução que consta da Conferência das Nações Unidas sobre Meio Ambiente e Desenvolvimento: Relatório da Delegação Brasileira, Brasília, Fundação Alexandre de Gusmão - FUNAG, 1993, Introdução, p. 36. No original do "Report of the United Nations Conference on Environment and Development" consta: "In order to protect the environment, the precautionary approach shall be widely applied by States according to their capabilities. Where there are threats of serious or irreversible damage, lack of full scientific certainty shall not be used as a reason for postponing cost-effective measures to prevent environmental degradation"

6 Há autores que se referem a um número menor, porque o representante da União Européia subscreveu a Declaração como uma única parte, obrigando a todos os países que a integram, tal como previsto no Tratado.

7. Conferência das Nações Unidas sobre Meio Ambiente e Desenvolvimento: Relatório da Delegação Brasileira, cit., p. 36: "No Plenário foram igualmente adotadas as decisões finais da Conferência."

8 KISS, Alexandre; BEURIER, Jean-Pierre. Droit international de l'environnement. 3. ed. Paris: Pedone, 2004. p. 136-137. 
conhecimento incerto são passíveis de prevenção. A precaução se diferencia da prevenção porque esta procura evitar danos "cujas causas são bem conhecidas, com o fim de evitar ou minorar significativamente os seus efeitos" 9

A partir da ECO-92 o meio ambiente surge, entre outros bens, como uma instituição que necessita de uma nova visão ética. Ainda que o avanço, no que se refere à ética, não ocorra apenas pelo aperfeiçoamento das instituições jurídicas e da organização de poderes, é certo que a sua transformação é condição necessária para a eficácia da tutela ambiental. Desta forma, as deliberações políticas e jurídicas que se fixam em critérios, meramente técnicos, não conseguem evitar as tragédias decorrentes da intervenção humana sobre a natureza. A incapacidade do poder público lidar com elas são noticiadas diariamente.

A alteração climática, os desmoronamentos e transbordamentos de rios, o rompimento de barragens, são alguns exemplos das graves ameaças que atingem milhares de pessoas nas cidades e no campo. Não só no Brasil, mas no mundo revela-se total descaso diante da possibilidade previsivel de tragédias. Os governantes e os empresários, na sua maioria, estão mergulhados em discussões sobre a crise econômica e acabam gastando mais na reparação das catástrofes do que em medidas de prevenção. Ao lado dos danos visíveis existem os danos invisíveis - como os decorrentes da radiação - que não têm cheiro, não têm cor e só podem ser constatados por especialistas ou por instrumentos de alta tecnologia. Sem informação adequada, a população acredita na segurança das novas tecnologias que podem, ao contrário do que geralmente se pensa, representar um retrocesso.

A ética proposta por Aristóteles ${ }^{10}$ pressupunha a existência de um ser humano bom que em face das contingências da vida agia com virtude e sabedoria. As máximas tradicionais, dirigidas a um ser humano na sua relação com "o outro" restringiam-se ao tempo presente ou no máximo à duração previsível das suas vidas. As consequências de longo prazo (tempo futuro) eram deixadas ao acaso ou destino.

A ética, nesse sentido aristotélico, não fornece meios para uma decisão adequada em face das questões ambientais. O bom senso e a boa vontade ${ }^{11}$ do ser humano não são suficientes para a solução de problemas cujas consequências maiores se localizam no futuro. Segundo Celso Lafer:

A complexidade do mundo contemporâneo tornou a virtude da prudência um instrumento insuficiente para lidar com as contingências do futuro. É por essa razão que a ela hoje se

\footnotetext{
9 ARAGÃO, Maria Alexandra de Souza. Direito comunitário do ambiente. Coimbra: Almedina, 2002. p. 21.

10 ARISTÓTELES. Ética a Nicômacos. Tradução do grego, introdução e notas de Mário Gama Kury. 4. ed. Brasília: Editora Universidade de Brasília, 2001. Livro V.

1 KANT, Immanuel. Prolegómenos a toda metafisica futura. Lisboa: Edições 70, 1987. p. 52.
} 
agregam os instrumentos técnicos que ajudam a tomada de decisões em condições de incerteza. ${ }^{12}$

Os problemas ambientais dependem de uma ética que inclua a preservação da humanidade, pois o ser humano não pode ser objeto de apostas. ${ }^{13}$ Essa preeminência do ser humano no universo foi relatada por Kant na "Fundamentação da metafísica dos costumes" na qual ele explica o fundamento da vida ética. Kant afirma que toda pessoa é em si mesma uma finalidade, não pode ser considerada uma coisa ou uma mercadoria. Nas suas palavras:

O homem, e, duma maneira geral, todo o ser racional, existe como fim em si mesmo, não só como meio para o uso arbitrário desta ou daquela vontade. Pelo contrário, em todas acções, tanto nas que se dirigem a ele mesmo como nas que se dirigem // a outros seres racionais, ele tem sempre de ser considerado simultaneamente como fim. ${ }^{14}$

As decisões sobre os problemas ambientais devem considerar as consequências delas no longo prazo, segundo parâmetros éticos, com o fim de assegurar a existência presente e futura da humanidade. ${ }^{15}$

O sistema jurídico, que já sofre os efeitos da globalização, não dá conta dos conflitos entre as normas que envolvem os problemas ambientais, o que acaba ampliando o sentimento de incerteza e insegurança social.

2. O sistema piramidal e a nova temporalidade

Na ordem antiga o movimento era cíclico, o universo possuía um centro e o tempo era contínuo e cronológico. Os astros obedeciam ao ritmo cósmico. A modernidade inaugura uma nova noção de tempo e espaço: o espaço torna-se infinito, agrega e desagrega, e o tempo não tem mais uma sucessão linear, ele torna-se descontínuo e fragmentado. Conforme Octávio Paz:

O saber antigo tinha por fim último a contemplação da realidade, fosse presença sensivel ou forma ideal; o saber da técnica aspira substituir a realidade real por um universo de mecanismo. Os artefatos e utensilios do passado estavam no espaço; os mecanismos modernos alteram-no radicalmente. O espaço não só se povoa de máquinas que tendem ao automatismo ou que já são autômatos, como é o campo de

\footnotetext{
12 LAFER, Celso. Governança e risco O Estado de São Paulo, São Paulo, 18 maio 2003. Espaço aberto.

13 JONAS, Hans. Ética, medicina e técnica. Lisboa: Passagens, 1994; [...], cit., p. 83-88. O principio responsabilidade

14 KANT, Immanuel. Fundamentação da metafisica dos costumes. Rio de Janeiro: Edições 70, 1991. p. 68.

15 JONAS, Hans. O dever para com o futuro. O principio responsabilidade..., cit., p. 89- 97.
} 
forças, um entrelace de energias e relações - algo muito distinto dessa extensão ou superfície mais ou menos estável das antigas cosmologias e filosofias. O tempo da técnica e, por um lado, ruptura dos ritmos cósmicos das velhas civilizações; e por outro lado, aceleração e, por fim, abolição do tempo cronométrico moderno. De ambos os modos é um tempo descontínuo e vertiginoso que elude, se não a medida, a representação. ${ }^{16}$

Ocorre que os homens de poder e os do poder se preocupam com os problemas ambientais apenas no nível retórico, adotando medidas imediatas que não conseguem evitar os danos irreversíveis ao meio ambiente. O tempo presente é o que orienta a tomada das suas decisões. Eles consideram que os fins são postos muito diretamente, e o objetivo do exercício do poder é encontrar os meios apropriados para atingi-los. Eventos extremos, como chuvas volumosas, explosões de subestações de energia elétrica, poluição do ar por emissões de veículos, poluição por radiação eletromagnética, rios tomados pelo lixo, hão de ser considerados após a catástrofe ou pela ação judicial da população em busca dos seus direitos no judiciário. O tempo futuro a Deus pertence.

Do exame de problemas ambientais relativos à radiação eletromagnética, constatamos em pesquisa de mais de sete anos, ${ }^{17}$ que muitos foram decididos, considerando-se os padrões economicistas referidos ao tempo presente, ou seja, dentro de uma temporalidade regular ou dogmática. ${ }^{18}$ Como ensina François Ost:

Sin embargo, hoy en día, en el marco de los sistemas jurídicos 'super complexos' que acompañan al establecimiento de lo que se ha dado en hamar 'Estado-providencia' este equilibrio parece comprometido. En efecto, desde el momento en que el derecho no se contenta con arbitrar las relaciones sociales, sino que se presenta como agente del cambio social, deja de referir-se a un interés general, concebido en términos abstractos y estáticos, para determinarse en función de objetivos dinámicos, es decir, prospectivos. En estas condiciones, la estabilidad y la rigidez de la regla de derecho clásica pasan a ser obstáculos que hay que superar: la norma adoptará una forma flexible y adaptativa, se llamará plan, ley habilitación, ley orientación. La forma jurídica será ahora el objeto de una instrumentalizacion al servicio de los objetivos definidos por disciplinas externas al

16 PAZ, Octávio. Os signos em rotação. In: SIGNOS em rotação. São Paulo: Perspectiva, 2005. p. 103.

17 BOITEUX, Elza Antonia Pereira Cunha; BOITEUX, Fernando Netto. Poluição eletromagnética e o meio ambiente: o princípio da precaução. Porto Alegre: Sergio Fabris, 2008.

18 KERCHOVE, Michel Van de; OST, François. Las multiples temporalidades de los sistemas jurídicos. In: EL SISTEMA jurídico entre orden y desorden. Madrid: Servicio de Publicaciones de la Facultad de Derecho de La Universidad Complutense de Madrid, 1997. p. 189; De la pyramide au réseau? Pour une théorie dialectique du droit. Bruxelles: Facultés Universitaires Saint-Louis, 2002. 
derecho: economía, ciencia de la 'organización' medicina, psiquiatría $[\ldots]^{19}$

Mas isso não é tudo: os meios de comunicação também alteram a noção de tempo, pois a facilidade de comunicação representa uma das principais características da "globalização". Como ressalta Celso Lafer, a globalização "encurtou os espaços e acelerou o tempo" ${ }^{20}$ Ainda que o tempo das relações econômicas possa ser considerado diverso, a facilidade de comunicação é um dos elementos integrantes da globalização. ${ }^{21}$

Assim, a coexistência de uma ordem internacional com uma ordem comunitária e diversas ordens nacionais, que se manifestam a um só tempo, evoca a necessidade de articulação e harmonização entre as várias normas e as sanções impostas pelos vários sistemas. Neste sentido, o Professor Mario Losano, em diversos trabalhos, ${ }^{22}$ mas principalmente em conferência proferida na Ordem dos Advogados de São Paulo, esclareceu: ${ }^{23}$

[...] hoje, o direito assume o aspecto de uma massa tridimensional, em expansão contínua e irregular; portanto, o rigoroso modelo da pirâmide normativa está se desagregando. O direito moderno acha-se explicado só parcialmente no bem calibrado ordenamento hierárquico da pirâmide. Aquilo que fica fora da pirâmide é exatamente o que há de mais novo. Portanto, as alterações profundas no direito atual obrigam, em seu estudo, uma mudança de paradigmas. O modelo da rede substitui o da pirâmide.

Cada vez mais aberto, cada vez mais permeável, ${ }^{24}$ o sistema jurídico contemporâneo está sujeito a critérios que vêm de outras áreas de conhecimento e que, ao lado da técnica, ${ }^{25}$ incorporam valores, princípios, e conceitos indeterminados. O clássico

19 KERCHOVE, Michel Van de; OST, François. Las multiples temporalidades de los sistemas jurídicos. In: EL SISTEMA jurídico entre orden y desorden. Madrid: Servicio de Publicaciones de la Facultad de Derecho de La Universidad Complutense de Madrid, 1997. p. 192-193.

20 LAFER, Celso. Brasil: dilemas e desafios da política externa. USP: Estudos Avançados, n. 38, jan./abr. 2000, p. 260-267, citação de p. 264.

21 STIGLITZ, Joseph E. A globalização e seus maleficios. São Paulo: Futura, 2002. p. 36. Citamos: "Fundamentalmente, é a integração mais estreita dos países e dos povos do mundo que tem sido ocasionada pela enorme redução de custos de transporte e de comunicações e a derrubada de barreiras artificiais aos fluxos de produtos, serviços, capital, conhecimento e (em menor escala) de pessoas através das fronteiras." LOSANO, Mario G. Os grandes sistemas jurídicos: introdução aos sistemas jurídicos europeus e extraeuropeus. São Paulo: Martins Fontes, 2007. Sistema e Struttura nel Diritto. Milano, 2002. v. 1 .

23 LOSANO, Mario G. Modelos teóricos, inclusive na prática: da pirâmide à rede. Novos paradigmas nas relações entre direitos nacionais e supraestatais. Revista do Instituto dos Advogados do Estado de São Paulo, São Paulo, v. 8, n. 16, p. 264-284, 2005.

${ }^{24}$ ZAGREBELSKI, Gustavo. El derecho dúctil. Ley, derechos, justicia. Madrid: Editorial Trotta, 2003.

25 COMPARATO, Fábio Konder. Os princípios éticos sob o aspecto teleológico: ética e técnica, idealismo e realismo. In: ÉTICA: Direito, moral e religião no mundo moderno. São Paulo: Companhia das Letras, 2006. p. $499-505$. 
modelo hierárquico e piramidal não serve como paradigma para a tomada de decisão frente aos problemas ambientais. ${ }^{26}$

\section{O sistema em rede}

O modelo kelseniano foi bem sucedido no contexto europeu do século XIX, cujos Estados estavam organizados sobre uma realidade social industrial. Segundo Tércio Sampaio Ferraz Júnior, a característica essencial deste ente abstrato "Estado" era a noção de soberania, de modo que "o direito de soberania se transforma também num direito de sistematização centralizada das normas de exercício de poder de gestão." ${ }^{.27}$

Assim como Kelsen, muitos juristas reconhecem como única fonte do Direito o ordenamento jurídico estatal, ou seja, apenas as normas resultantes de atos decisórios do Estado. Para eles, o Direito é ordenamento unitário e escalonado de normas:

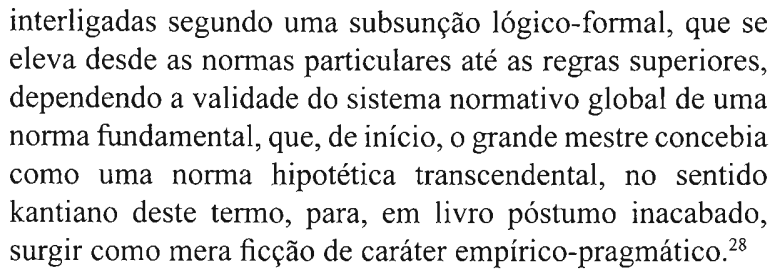

Esse modelo hierárquico e piramidal teve como uma de suas consequências práticas o surgimento da Corte constitucional, com a função de impedir a incoerência interna da pirâmide, eliminando as normas que contrariassem a Constituição. Nas palavras de Mario Losano são duas as consequências práticas do modelo kelseniano: a) a formação da Corte Constitucional austríaca, responsável por zelar pelo cumprimento da Constituição com regras processuais do próprio sistema, de modo a garantir a existência do ordenamento jurídico e do Estado de Direito; $b$ ) a exigência de respeito pelo direito internacional pela ordem nacional em tempos de crise e violência. ${ }^{29}$

A concepção kelseniana exige que as normas estatais e internacionais convivam dentro de um sistema jurídico único, orientado por uma única norma fundamental. Desse modo, a questão do nível no qual o direito internacional se encontra na pirâmide assume fundamental importância: se ele se coloca acima da Constituição, ela deve conformidade a ele; se ele se coloca abaixo dela, deve a ela se conformar.

26 KELSEN, Hans. Teoria pura do direito. 4. ed. Coimbra: Armênio Amado, 1976.

27 FERRAZ JR., Tércio Sampaio. Introdução ao estudo do direito: técnica, decisão, dominação. São Paulo: Atlas, 2010. p. 178.

28 REALE, Miguel. Fontes e modelos do direito: para um novo paradigma hermenêutico. São Paulo: Saraiva, 1994, p. 88.

29 LOSANO, Mario G. Modelos teóricos, inclusive na prática: da pirâmide à rede... cit., p. 270-271. 
Os juristas não podem esqueçer que a tese kelseniana foi pioneira no estudo do ordenamento jurídico enquanto sistema de normas, e têm seus méritos. ${ }^{30}$ Ao analisar a transição da "teoria da norma" para a "teoria do ordenamento", Bobbio observa:

O trabalho de Kelsen consiste, ao contrário, em não abandonar o ponto de vista normativo na passagem do estudo das normas singulares para o estudo do ordenamento, mas sim em conduzi-lo às últimas conseqüências, tratando o elemento característico do direito no modo com que as normas às quais damos o nome de normas jurídicas se dispõem e compõem em sistema. Assim junto à nomostática, que é a teoria da norma jurídica, ganha lugar no sistema kelseniano a nomodinâmica, que é a teoria do ordenamento jurídico. ${ }^{31}$

Entretanto, o aumento da normatividade no âmbito do direito internacional, juntamente com um número cada vez maior de instituições internacionais especializadas, também ampliou o potencial conflito entre as normas internacionais de diferentes naturezas. A proliferação de normas no âmbito internacional colocou em xeque a tradicional ideia de unidadade, coerência e completude do sistema jurídico. Celso Lafer afirma: "Os ordenamentos juridicos das sociedades contemporâneas têm uma complexidade que deriva da multiplicidade das fontes do Direito" ${ }^{32}$ Por essa razão, o direito internacional constitui um importante campo para a reflexão jurídica, pois a sua complexidade é intensa, com normatividade cada vez mais especializada e cada vez mais self-contained.

Além disso, o multiculturalismo e os direitos humanos ultrapassam as fronteiras físicas e jurídicas atingindo as ordens nacionais. Assim, o desenvolvimento das sociedades multiculturais corresponde ao reconhecimento, pelo ordenamento jurídico internacional, da identidade cultural da pessoa. Os problemas interculturais requerem técnicas novas para a solução dos conflitos, bem como o respeito aos preceitos e costumes culturais. O discurso sobre tolerância invade o cenário político e jurídico, mas aqueles que se consideram diferentes querem ser respeitados e não apenas tolerados.

$\mathrm{O}$ artigo 27 do Pacto Internacional dos Direitos Civis e Políticos reconhece que as pessoas pertencentes a minorias étnicas, religiosas ou linguísticas "não poderão ser privadas do direito de ter, conjuntamente com outros membros de seu grupo, sua própria vida cultural, de professar e praticar sua própria religião e usar sua própria língua" 33

30 BOBBIO, Norberto. "Nunca será demais insistir no fato de que foi com Kelsen que, pela primeira vez, a teoria do direito orientou-se definitivamente para o estudo do ordenamento jurídico como um todo, considerando como conceito fundamental para uma construção teórica do campo do direito não mais o conceito de norma, mas o de ordenamento entendido como sistema de normas." BOBBIO, Norberto. Da estrutura à função: novos estudos de teoria do direito. Barueri: Manole, 2007. p. 195.

31 BOBBIO, Norberto. Direito e poder. São Paulo: Editora UNESP, 2008. p. 105 e 110.

32 LAFER, Celso. Norberto Bobbio, teoria do ordenamento jurídico. In: CARDIM, Carlos Henrique (Org.). Bobbio no Brasil: um retrato intelectual. Brasilia: UNB; São Paulo: Imprensa Oficial do Estado, 2001. p. $75-80$.

33 Regulamentada pela Declaração sobre os Direitos das Pessoas Pertencentes a Minorias Nacionais ou Étnicas, 
O direito internacional moderno protege a identidade cultural da pessoa ao invés de agir, como no passado, favorecendo a gradual assimilação de uma minoria étnica. A Comissão para Proteção dos Direitos do Homem de Estrasburgo mostrou que a ampliação do direito à diferença compreende também a proteção à pessoa de um estilo de vida próprio. ${ }^{34}$

A aplicação das normas do direito internacional privado não permite, muitas vezes, a utilização do clássico sistema piramidal, pois a experiência jurídica aponta para a pluralidade de ordenamentos jurídicos dentro de um mesmo território que podem estar relacionados ao nível nacional ou internacional. A correlação entre essas ordens jurídicoinstitucionais e o ordenamento jurídico-estatal é explicada de diferentes modos, mas Miguel Reale afirma que a visão do pluralismo constrói-se:

aceitando, de um lado, a pluralidade dos ordenamentos jurídicos como realidades sociais autônomas, e não apenas permitidas ou consentidas pelo Estado, e, de outro lado, reconhecendo que há uma "graduação da positividade jurídica", com predomínio do ordenamento jurídico-estatal, que atuaria como "lugar geométrico" dos demais sistemas de normas. ${ }^{35}$

Em contraposição ao modelo da pirâmide, Reale afirma que o ordenamento jurídico se apresenta:

[...] mais como um ecossistema complexo e variado, que abrange uma multiplicidade de sistemas e subsistemas normativos que se escalonam uns distintos dos outros, em função de diversos campos de interesse, muito embora todos eles se situem e se insiram no âmbito do comum horizonte de validade da Constituição de cada povo (Direito Interno) ou, então, sob o horizonte de coexistência universal exigido pelo comunitas gentium para sobrevivência e desenvolvimento dos povos em igualdade de direitos (Direito Internacional). ${ }^{36}$

A expansão dos direitos humanos, a elaboração de novas categorias que não se referem a um sujeito específico, mas interessam à humanidade como um todo, não se enquadram no modelo piramidal que exige unidade, coerência e a uma só norma de fechamento do sistema. Os conflitos ligados às questões coletivas exigem um modelo marcado por remissões explícitas a várias ordens, na maioria das vezes sucessivas,

Religiosas e Linguísticas, aprovada pela Assembléia Geral das Nações Unidas em 18 de dezembro de 1992.

34 JAYME, Erik. Sociedade multicultural e novos desenvolvimentos no direito internacional privado. Cadernos do Programa de Pós-graduação em Direito, v. 1, n. 1, mar. 2003. p. 95.

35 REALE, Miguel. Fontes e modelos do direito: para um novo paradigma hermenêutico. São Paulo: Saraiva, 1994. p. 89.

36 REALE, Miguel. cit., p. 97. 
sem rígidez, mas que permite encontrar um critério de justo reconhecido pelas partes envolvidas: a rede.

Mas não é só: o direito regional alcança proporções nunca antes vistas, com o nascimento de um novo tipo de ordenamento, o supraestatal, que se soma aos outros, o nacional e internacional. A Organização dos Estados Americanos (OEA), a União Europeia (UE) e o próprio Mercosul são exemplos de organizações que interferem nos ordenamentos estatais e trazem implicações também no âmbito internacional.

A regulação de setores cada vez mais amplos da vida social, abrangendo áreas antes pouco exploradas, como é o caso dos direitos coletivos e os direitos metaindividuais, dá origem a uma gama de microssistemas legais, estruturados em distintas cadeias normativas. Essa esfera principiológica, que muitas vezes se confunde com a própria esfera valorativa, sempre em busca da "ética da situação", ${ }^{37}$ já não se restringe ao âmbito constitucional ou ao âmbito dos direitos fundamentais, mas busca na interdisciplinaridade do conhecimento as razões para obter uma justiça solidária.

O novo paradigma reticular com base na teoria dos sistemas, proposta por Niklas Luhmann, mostrou que o sistema jurídico, diante da complexidade do ambiente social, de forma autorreferencial, se especializa, definindo o seu ambiente interior e seu entorno, tornando-se operativamente fechado, mas mantendo a abertura cognisciva. Apesar de ser autopoiético, o sistema continua influenciado pelo meio externo. Em outras palavras, o sistema é fechado operativamente, não se submete a qualquer princípio fundador ou metanorma exterior a ele, mas recebe influência cognisciva do ambiente que compõe o seu entorno. ${ }^{38}$ Isto ocorre porque a legitimação do direito, neste modelo, só pode se dar internamente, pelo procedimento que garanta "a obtenção de uma disposição generalizada para aceitar decisões de conteúdo ainda não definido" 39

O modelo reticular é fortemente influenciado pela cibernética e pela informática, reconhecendo que a sistematização do direito evolui com a sociedade onde o Estado não mais figura como o único centro emanador de normas. Desta forma, o modelo piramidal existe ao lado do reticular, solúvel e policêntrico, ou seja, ele não desaparece e nem é superado, pois os dois modelos são coexistentes, com métodos diversos, porém essenciais. A pirâmide representa a estrutura do direito, e a rede representa a sua função.

Segundo Mario Losano, a técnica de remissão a outros textos normativas empreendida pelos positivistas convencionais ainda é necessária no contexto do sistema

37 REALE, Miguel. O projeto de código civil: situação atual e seus problemas fundamentais. São Paulo: Saraiva, 1986. p. 39.

38 OST, François; KERCHOVE, Michel van de. El sistema juridico entre orden y desorden, cit., p. 104.

39 VILLAS BOAS FILHO, Orlando. O direito na teoria dos sistemas de Niklas Luhmann. São Paulo: Max Limonad, 2006. p. 231 
em rede, especialmente porque a quantidade de normas que se entrelaçam é enorme. ${ }^{40}$ Ele afirma que uma teoria científica não é uma questão de fé:

Invece una teoria scientifica, a mio giudizio, vive e sopravvive per aggiustamenti e correzioni successive. Non offre un sistema di certezze incrollabili, ma un insieme di spiegazioni plausibili e storicamente condizionate. Il mondo delle scienze sociali e di quelle naturali è pieno di teorie che passano da uno studioso all'altro o da una gerazione all' altra con aggiunte o mutilazioni, in un lavorio di lima di cui, dopo secoli, della dottrina originaria resta poco più che ricordo. ${ }^{41}$

4. O progresso científico e o meio ambiente

Enquanto no século XIX o desenvolvimento da ciência nos deu a base para a revolução industrial e uma nova visão do planeta terra, o progresso científico ao longo do século XX foi fundamental para a compreensão dos processos que envolvem os problemas ambientais. Na primeira metade do século XX as descobertas científicas mostraram as limitações da física de Newton, alterando as noções de tempo e espaço. ${ }^{42}$ A repercussão no âmbito jurídico foi muito ampla, e dela decorreu a reformulação de diversos conceitos. Como explica Mario Losano:

Lo spazio statale - il vecchio "territorio dello Stato" - è oggi superato non soltanto dalle regole di origine non statale (il cd. soft law, inteso nel senso più lato), ma che dalle esigenze geopolitiche di natura energetica o militare. La geopolitica del petrolio sta ridisegnando nuove alleanze e nuovi conflitti territoriali: in essi, i discorsi di potere ideologico o politico si intersecano con le pressioni e le regole delle compagnie petrolifere. La prevedibile insufficienza di cibo sta portando la Cina ad accaparrarsi terre in Africa. La crisi dell'acqua porta a tensioni fra Stati nazionali, quando uno di questi costruisce dighe sui fiumi, precludendone l'acqua ad altri

40 LOSANO, Mario G. Modelos teóricos, inclusive na prática: da pirâmide à rede. Novos paradigmas nas relações entre direitos nacionais e normativas supraestatais, cit., p. 282.

41 LOSANO, Mario G. Si può acettare solo in parte la teoria di Kelsen? Dialogo com Luis Martínez Roldán. Rivista Internazionale Di Filosofia Del Diritto, set. 2007. p. 381.

42 ESCOBAR, Carlos. Um difícil legado. Revista Fapesp: O universo além da física, fev. 2009, p. 6-7: "Para Newton o tempo fluía de modo igual para todos os observadores. Einstein não gostava de tempo e espaço absolutos, ele os queria dinâmicos! Com esse propósito começou a trabalhar em experiências mentais que se assemelhavam ao que Galileu já havia feito, ao imaginar um barco em movimento no mar tranquilo ele se perguntava onde cairia uma pequena bola que um marujo soltasse do alto do mastro. Os pensadores antigos diriam que a bola cairia para trás do pé do mastro, em direção à popa, mas na verdade a bola cai ao pé do mastro, como se o barco estivesse parado. [...] Como resultado, em 1905 Einstein apresentou a teoria da relatividade especial, mostrando o que Poincaré e o fisico holandês Hendrik Lorens não haviam visto: a simultaneidade - o próprio tempo - depende do observador" 
Stati; ma al tempo stesso le lobbies e il soft law delle multinazionali delle bevande stanno spingendo verso una privatizzazione dell'acqua: un bene dal mercato sicuro e inesauribile. ${ }^{43}$

Se os juristas conseguiam separar a propriedade particular da pública, hoje, a definição do que é um bem ambiental é o seu maior desafio. A paisagem deve ser considerada um bem público ou particular? Ela integra o conceito de propriedade? Nas propriedades situadas à beira-mar, o que está em jogo não é apenas a vista no sentido estético, mas o fato de que a alteração da paisagem poderá alterar o clima da cidade, mudar as correntes e circulação de ar para as residências que ficam no continente. A alteração da paisagem, por intervenção humana, poderá trazer danos à cidade e não apenas à propriedade individual e vizinha.

Qual é o limite tolerável de mudança paisagística, decorrente da intervenção humana? A paisagem é um bem natural ou um bem cultural? As dificuldades são muitas, entre elas está o fato de que esse conceito envolve um juízo de valor e o fato dele ser um elemento fundamental para a qualidade de vida dos seres humanos. A paisagem é uma categoria dinâmica que depende da elaboração e construção dos juristas, considerando o progresso da ciência. Se a paisagem é algo visível, o progresso da ciência também altera aquilo que não se encontra visível para o cidadão comum.

José Goldemberg, Professor Titular da USP, em artigo sobre a ciência no século 21, informa-nos que a descoberta da radioatividade foi um grande avanço, pois os átomos são estruturas complexas que podem libertar enormes quantidades de energia armazenadas neles, por meio de explosões nucleares, ou de reatores capazes de produzir calor e eletricidade. ${ }^{44}$ A eletricidade não é visível, mas traz benefícios e conforto às pessoas.

Ocorre que a radiação produzida pelas linhas de alta tensão também é invisível e nada se menciona sobre ela quando se deseja vender mais energia. Ao lado dos benefícios encontram-se riscos não informados aos usuários, que podem trazer danos irreversíveis às pessoas. A informação adequada é uma garantia necessária para a população. Embora a técnica invente todos os dias algo de novo, ela nada pode nos dizer sobre o futuro. É a consciência ética da sua aplicação que pode evitar danos para a humanidade.

No Brasil, um exemplo de aplicação ética da técnica foi desenvolvido pela pesquisadora Anna Lúcia Villavicencio, do Instituto de Pesquisas Energéticas e Nucleares

43 LOSANO, Mario G. La dilatazione dello spazio: dallo spazio terrestre allo spazio celeste. Diritto e geografia - Lo spazio del diritto e il mondo della geografia, p.9.

44 GOLDEMBERG, José. A ciência no século 21. O Estado de São Paulo, São Paulo, 26 dez. 1999. 
(IPEN). A sua pesquisa concluiu que a radiação ionizante ${ }^{45}$ é uma técnica eficiente para a esterilização do palmito pupunha.

Ela destaca que o procedimento, que é feito dentro de irradiadores de cobalto 60 aceleradores de electrons, permite romper as células de fungos bactérias, leveduras sem alterar o sabor da textura do palmito. Com isso o alimento chega a durar 15 dias. $^{46}$

Este procedimento atende aos critérios econômicos porque é mais barato que a esterilização química, mas também atende aos critérios éticos ao aumentar a qualidade do produto e a sua conservação. Em face da crise mundial da fome planetária, esta descoberta ultrapassa a técnica tradicional para a conservação dos alimentos e nos faz lembrar de Denis Papin, ${ }^{47}$ no século XVII, que não patenteou as suas descobertas por considerá-las uteis para a humanidade. Todavia, nem sempre as coisas se passam dessa maneira. Muitas vezes os critérios econômicos, a pretexto do desenvolvimento desejado são os únicos levados em consideração para a tomada de decisão.

A transmissão e distribuição de energia elétrica $(50 / 60 \mathrm{~Hz})$ expõe as pessoas a campos eletromagnéticos de frequências extremamente baixas, conhecidos como radiação não-ionizante ou CEM. Essa radiação difere da radiação ionizante porque não consegue quebrar as ligações que mantêm as moléculas ligadas em células e, desta forma, não produzem ionização. ${ }^{48}$ Aparentemente inofensiva, a energia elétrica pode ser considerada uma forma de contaminação, e deve ser objeto de fiscalização pública a maneira como é distribuida. ${ }^{49}$

A biologia é outra área importante, graças à revolução genômica do século XXI. Entretanto, não basta conhecer e analisar os genes ou os dados físico-químicos de uma descoberta, faz-se necessário analisar em qual contexto eles surgiram, em que situação ocorreram determinadas alterações genéticas. Conforme explica o biólogo

45 BOITEUX, Elza Antonia Pereira Cunha; BOITEUX, Fernando Netto. Poluição eletromagnética e o meio ambiente: o princípio da precaução, cit, p. 15. "As radiações ionizantes são estudadas há mais tempo que as demais, e por essa razão os seus efeitos são mais bem conhecidos; a titulo de exemplo, podemos lembrar que, desde a década de 1950 o uso de aparelhos de raios $X$ é vedado nos exames a serem realizados em gestantes e que o Brasil é signatário da Convenção da OIT número 115, que dispõe sobre a proteção dos trabalhadores contra as radiações ionizantes"

46 COSTA, Leandro. Radiação esteriliza palmito. O Estado de São Paulo, São Paulo, a. 56, n. 2.875, 15 a 21 dez. 2010. Caderno Agrícola do Jornal. p. 9.

47 WITKOWSKI, Nicolas. Uma história sentimental das ciências. Rio de Janeiro: Jorge Zahar, 2004; narra uma série de descobertas e invenções que não se enquadraram na lógica racional da época em que foram realizadas. A história de Papin encontra-se nas p. 45-49. Enquanto fazia o doutorado desenvolveu a tecnologia da "bomba a vácuo" e realizou pesquisas inéditas sobre a conservação dos alimentos que permitiu conservar uma maçã durante cinco meses, no vácuo.

48 BOITEUX, Elza Antonia Pereira Cunha; BOITEUX, Fernando Netto. Poluição eletromagnética e o meio ambiente: o princípio da precaução, cit, p. 15-16.

${ }_{49}$ Lei n. $6.938 / 91$, no seu art. $3^{\circ}$, inciso III, alínea "e", afirmou que "lançar energia" é uma maneira de poluir o meio ambiente. 
evolucionista Alan Templeton: "os genes podem sofrer alterações e mudar os nossos traços, mas mudanças no ambiente também podem afetar nossas características. O DNA não é tudo" ${ }^{50}$ Os genes interagem o tempo todo com o meio ambiente. No campo jurídico, as doações de órgãos, fertilização in vitro, os fetos anencefálicos, a filiação biológica e por afinidade, estão entre os temas de mais difícil decisão.

As descobertas científicas têm impacto sobre o meio ambiente, razão suficiente para não se desconhecer a sua aplicação. Carlos Henrique Brito Cruz, director científico da Fapesp, lembra que a busca do conhecimento e o paradoxo de consequências inesperadas acompanham a humanidade há muito tempo. Ele afirma que "conhecer mais $e$ melhor é tão importante quanto conhecer mais para criar aplicações" 51

A ciência demonstrou que o nosso planeta é especial, graças a fatores que resultam da possibilidade de manutenção de formas superiores de vida, o que não acontece nos outros planetas. Graças à solidariedade do mundo animal que resultou no processo de integração entre elementos vivos, que vão desde microorganismos às plantas, dos animais aos demais elementos vivos, podemos mostrar a integração dos elementos bióticos e abióticos, além dos gases que formam a atmosfera, os minerais. Ou seja, tudo que integra a Terra como um planeta complexo.

Os direitos individuais adquirem uma função ambiental, pois a Natureza, como um bem de uso comum, impõe a aplicação do interesse coletivo sobre o individual. O paradigma ambiental ${ }^{52}$ com fundamento na solidariedade parte do coletivo para atingir o individual, de forma que a propriedade é limitada por sua função social. A hermenêutica jurídica depende do método holístico, que analisa a natureza, o direito e o ser humano na sua totalidade. Finalmente, a técnica deve ser direcionada por uma nova ética.

\section{A energia elétrica e a qualidade de vida}

No Direito brasileiro o meio ambiente é definido como um complexo de relações entre o mundo natural e os seres vivos que influencia a sua vida e o seu comportamento. ${ }^{53}$ A mesma definição é encontrada na Lei n. 6.938/81, que dispõe sobre a Politica Nacional do Meio Ambiente (art. $3^{\circ}$, inciso I), ao afirmar que o meio ambiente é " $O$ conjunto de condições, leis, influências e interações de ordem fisica, química $e$ biológica, que permite, abriga e rege a vida em todas as suas formas"

so TEMPLETON, Alan. A evolução humana nos últimos 2 milhões de anos: genes. Revista Pesquisa FAPESP, n. 147, maio 2008, p. 66.

51 CRUZ, Carlos Henrique de Brito. O avanço da ciência faz a humanidade melhor? Por que? Revista Pesquisa FAPESP, n. 147, maio 2008. p. 72.

52 LORENZETTI, Ricardo Luis. El paradigma ambiental. In: TEORIA de la decision Judicial: fundamentos de derecho. Buenos Aires: Rubinzal-Culzoni, 2006. p. 425-477.

53 SILVA, José Afonso da. Curso de direito constitucional positivo. São Paulo: Malheiros, 2000. p. 265. 
Portanto, o meio ambiente ecologicamente equilibrado é direito de todos, possui a natureza de um bem de uso comum do povo, sendo essencial à sadia qualidade de vida. ${ }^{54}$ Segundo a Constituição Federal Brasileira a defesa do meio ambiente está entre os princípios-fundamento da ordem econômica, admitindo o "tratamento diferenciado" das atividades conforme o impacto ambiental que produzam (art. 170, inciso VI) e impõe ao Poder Público, em todos os seus níveis (mas não só a ele), o dever de proteger o meio ambiente, conforme transcrito (art. 225, caput e $\S 1^{\circ}-$ itálicos apostos):

Art. 225. Todos têm direito ao meio ambiente ecologicamente equilibrado, bem de uso comum do povo e essencial à sadia qualidade de vida, impondo-se ao Poder Público e à coletividade o dever de defendê-lo e preservá-lo para as presentes e futuras gerações.

O termo "dever" aplica-se a todos, dos indivíduos às pessoas coletivas, das pessoas jurídicas particulares às pessoas jurídicas de direito público, uma vez que se destina à proteção de interesses de terceiros. ${ }^{55}$

$\mathrm{O}$ meio ambiente engloba elementos naturais, como o solo, a água, o ar atmosférico, a flora, a fauna; elementos culturais, como o patrimônio artístico, histórico, turístico, paisagístico, arqueológico, elementos artificiais, como o espaço urbano construído, e elementos do trabalho. ${ }^{56}$

A sociedade moderna depende, cada vez mais, de equipamentos elétricos e eletrônicos não só para o seu bem-estar e conforto, como também, para o desenvolvimento econômico e para a produção de bens necessários à sobrevivência de todos. A energia elétrica é necessária em hospitais, para tratamentos de saúde, para a manutenção dos chamados ambientes limpos e sem contaminação para cirurgias, etc. Ela é um bem fundamental para a vida das pessoas, para o desenvolvimento social e tecnológico de toda

\footnotetext{
Id. Ibid., p. 216.

ss GARCÍA DE ENTERRÍA, Eduardo; FERNÁNDEZ, Tomás-Ramón. Curso de derecho administrativo. 9. ed. Madrid: Civitas, 2004. p. 31; com a seguinte redação: "Deberes y obligaciones son dos especies de un género común, los deberes en sentido amplio, en cuanto comportamientos, positivos o negativos, que se imponen a un sujeto en consideración a intereses que no son los suyos propios, sino los de otro sujeto distinto o los generales de la colectividad".

56 Podemos fazer uma subdivisão para efeito de estudo analítico da seguinte forma: 1-Direito ao Meio Ambiente natural: composto pela fauna, flora, águas, biosfera, solo, ar atmosférico, com a interação dos seres vivos e de seu meio formando a Biota. 2- Direito ao Meio Ambiente cultural: tem-se por cultura a reunião de toda a experiência humana através dos tempos; a produção e preservação cultural é imprescindivel para o desenvolvimento da humanidade.3-Direito ao Meio Ambiente artificial: é o ramo que rege os assentamentos humanos. Há a obrigatoriedade de saneamento básico que de acordo com a Organização Mundial de Saúde, é o controle de todos os fatores do ambiente que exercem ou possam exercer efeitos deletérios sobre o bemestar físico, mental ou social do homem.4- Direito ao Meio Ambiente do trabalho diz respeito às relações entre a ocupação do indivíduo e o desenvolvimento de doenças. Em outras palavras, é o complexo de bens de uma empresa, objeto de direitos relativos à saúde e a integridade física dos trabalhadores.
} 
a sociedade. A questão que se coloca é: existe risco para a população que a utiliza? Existe risco para quem mora ao lado de uma linha de alta tensão?

Eletricidade e magnetismo são conceitos intimamente ligados. O campo eletromagnético formado pelas linhas de transmissão produz radiação não ionizante (ou radiação eletromagnética), ${ }^{57}$ que interage com os organismos vivos e altera as informações eletromagnéticas naturais que existem no meio ambiente. Embaixo de uma linha de transmissão de alta tensão os campos eletromagnéticos podem chegar a $12 \mathrm{KV} / \mathrm{m}$ e a 30 $\mathrm{mT}$ e nas imediações das estações e subestações geradoras, os índices podem chegar até $16 \mathrm{KV} / \mathrm{m}$ e $270 \mathrm{mT}$, enquanto o nível de segurança aceitável para a densidade do fluxo magnético é de, apenas, $1 \mathrm{mT}$. $^{58}$

Sergio Koifman em estudo epidemiológico realizado no Município de São Paulo no período de 1992 a 2002 mostrou que a associação entre a exposição aos campos eletromagnéticos e leucemia em crianças de zero a quatorze anos é preocupante. ${ }^{59}$

O estudo comparou a distribuição da radiação não ionizante no exterior de casas com óbitos infantis por leucemia, em relação as casas com óbitos infantis por causas não neoplásicas em áreas geograficamente similares. O resultado mostrou aumento da incidência de morte por leucemia infantil, em proporção maior do que doenças por causas não neoplásicas, conforme aumentava o percentual dos campos eletromagnéticos. Ou seja, houve crescimento do risco de morte por leucemia infantil conforme aumentava a intensidade do campo eletromagnético. Koifman concluiu que, com base nos resultados obtidos, é preciso adotar medidas para reduzir a exposição à radiação não ionizante.

Francisco Tejo, outro cientista brasileiro, em análise da natureza dos campos eletromagnéticos e sua interação com os sistemas biológicos, concluiu que os campos elétricos e magnéticos de $60 \mathrm{~Hz}$ induzem correntes elétricas sutis em organismos vivos. ${ }^{60}$ Segundo o seu trabalho, as exposições aos campos eletromagnéticos podem ser de dois tipos: aguda (curta duração e alta intensidade) ou crônica (duração prolongada e baixa intensidade). Os efeitos térmicos são localmente contrabalançados pelos mecanismos

57 BOITEUX, Elza Antonia Pereira Cunha; BOITEUX, Fernando Netto. Poluição eletromagnética e o meio ambiente: o princípio da precaução, cit, p. 21.

58 BOITEUX, Elza Antonia Pereira Cunha; BOITEUX, Fernando Netto. Poluiçâo eletromagnética e o meio ambiente: o princípio da precaução, cit. As informações acima foram extraídas da Nota Descritiva n. 205 de novembro de 1998 publicada pela Organização Mundial de Saúde - OMS.

59 KOIFMAN, Sergio. Exposição a campos eletromagnéticos de baixa frequência e mortalidade por leucemia na infância: análise exploratória de sua associação no Município de São Paulo. In: SEMINÁRIO INTERNACIONAL SOBRE RNI, A SAÚDE E O AMBIENTE, Porto Alegre, maio 2009. Disponivel em: $<$ http://www.ufrgs.br/ppgee/mitrabalhos/resumol4.doc >. Acesso em: 10 jul. 2009.

60 TEJO, Francisco. A. F. Impacto dos campos eletromagnéticos não ionizantes e a necessidade de adotar-se o princípio da precaução. In: SEMINÁRIO INTERNACIONAL SOBRE RNI, A SAÚDE E O AMBIENTE, Porto Alegre, maio 2009. Disponível em: <http://www.ufrgs.br/ppgee/rnitrabalhos/trabalho17.ppt>. Acesso em: 10 jul. 2009. 
de termo-regulação (passiva e ativa) e os efeitos não térmicos ocorrem em frequências específicas nos níveis celular e molecular. ${ }^{61}$

Francisco Tejo relata que as descobertas científicas sobre os eventos físicoquímicos e os campos eletromagnéticos causam o aumento do risco de enfarte, dano ao DNA que propricia o desenvolvimento de anomalias fetais, doenças denegerativas, como mal de Alzheimer e mal de Parkinson, câncer, debilitação do sistema imunológico e mudança nas funções cerebrais, que pode causar estresse, distúrbios hormonais, perda de memória recente, diminuição do aprendizado, cefaleia e fadiga. ${ }^{62}$

$\mathrm{O}$ desconhecimento quanto ao risco, ao perigo e às incertezas no tempo e espaço, impõem a aplicação do princípio da precaução. ${ }^{63}$ Isto é, se o dano tem probabilidade certa, sua magnitude é conhecida, aplica-se a prevenção, se o dano tem probabilidade incerta, a sua magnitude é desconhecida, incide a precaução. Portanto, a maneira pela qual a energia é distribuída, com maior ou menor segurança é questão de interesse público que se sobrepõe ao interesse particular de vender energia nas condições mais favoráveis para a empresa fornecedora, e não para a população atingida por essa atividade.

As distribuidoras de energia elétrica possuem tecnologia para diminuir a radiação ionizante a níveis considerados mais seguros para a população. Não só em propagandas, mas também nas revistas especializadas elas divulgam o emprego de novas tecnologias que permitem linhas subterrâneas e blindadas. ${ }^{64}$ Além disso, é possível manter substações e estações de energia longe dos bairros residenciais e distantes de escolas. O que não falta é tecnologia para uma distribuição segura, mas as empresas concessionárias consideram apenas os custos e lucros para optar pelo que é melhor para a população.

De outro lado, não podemos deixar o futuro à própria sorte. A gestão do risco é tarefa governamental, que não pode ser delegada às concessionárias de serviço público, permitindo que as mesmas determinem o nível de segurança para a população. Os estudos e pesquisas nacionais e internacionais indicam que o nível de segurança está muito distante daqueles praticados pelas empresas públicas ou concessionárias de energia elétrica. Não basta que a energia elétrica seja gerada sem prejuízo ao ambiente,

${ }_{61}$ TEJO, Francisco. A. F. Impacto dos campos eletromagnéticos não ionizantes e a necessidade de adotar-se o princípio da precaução, cit.

62 TEJO, Francisco A. F. Impacto dos campos eletromagnéticos não ionizantes e a necessidade de adotar-se o princípio da precaução, cit.

63 LOPEZ, Teresa Ancona. Princípio da precaução e evolução da responsabilidade civil. São Paulo: Quartier Latin, 2010.

64 A Edição n. 26 de Fevereiro de 2005, a Revista Pirelli Club informou : "com a experiência da Pirelli no campo de redes subterrâneas e a qualificação técnica das empresas parceiras neste projeto, a AES Eletropaulo entregou a linha Miguel Reale-Wilson" [...] e que nesta fase foi adicionada uma segunda linha de subtransmissão subterrânea, a LTS Miguel Reale-Cambuci. <http://www.prysmianclub.com.br/revista/ PClub_26/materias/alta.htm>. Acesso em: maio 2009. 
é necessário que ela seja distribuída sem prejuízo para a qualidade de vida das pessoas. Conforme explica José Afonso da Silva:

O homem é, a um tempo, resultado e artífice do meio que o circunda, o qual lhe dá o sustento material e o brinda com a oportunidade de desenvolver-se intelectual, moral e espiritualmente. [...] Os dois aspectos do meio ambiente, o natural e o artificial, são essenciais para o bem-estar do homem e para que ele goze de todos os direitos humanos fundamentais, inclusive o direito à vida mesma. ${ }^{65}$

O Tribunal Superior de Justicia de la Comunitat Valenciana, no exemplo que destacamos por se referir à distribuição de energia elétrica, tema que vem sendo examinado com rigor na jurisprudência espanhola, atribuiu maior eficácia a esse preceito, ao determinar:

Cuando subsistan dudas sobre la existencia o alcance de riesgos para la salud de las personas, las Instrucciones pueden adoptar medias de precaución sin tener que esperar a que se demuestre la realidad y gravedad de tales riesgos. ${ }^{66}$

O caso em tela se refere à construção de uma subestação de energía elétrica em área que, posteriormente à concessão da autorização, veio a se tornar área residencial. O Tribunal determinou a paralisação das obras no local originário, bem como a sua realização em local, considerando, de um lado, a possibilidade de incêndio nas subestações, que restou provada; de outro, a aplicabilidade do principio da precaução, nos seguintes termos:

Por último la consideración de la actividad como molesta e peligrosa, como hemos visto no resulta pacifica y la administración concedió previamente la licencia de obras, antes que se resolviese sobre la licencia de actividad, su inocuidad o peligrosidad, lo que lleva a la consideración de que no se valoró la ubicación de la actividad, en núcleo de población y la aplicación del artículo 4 del RAMINP, debiendo de interpretarse las normas aplicables al caso que nos ocupa, la instalación de una Subestación en suelo urbano densamente poblado y con instalaciones escolares cercanas, de acuerdo con la realidad social y el espíritu y la finalidad del derecho a disfrutar de un medio ambiente adecuado para el desarrollo de la persona que proclama la Constitución Española en su artículo $45[\ldots]^{67}$

\footnotetext{
65 SILVA, José Afonso da. Direito ambiental constitucional. 3. ed., rev. São Paulo: Malheiros, 2000. p. 58-59. 66 Apud Juzgado de lo Contencioso Dos de Valencia, Sentencia n. 168/08 a 13 de marzo de 2008, Juez Estrella Blanes Rodriguez. A decisão informa a fls 19 que essas considerações foram adotadas pelo Tribunal Supremo.

67 Juzgado de lo Contencioso Dos de Valencia, Sentencia n. 168/08, cit., p. 20.
} 


\section{O princípio da solidariedade}

A solidariedade é um valor ético-moral; no âmbito jurídico ela é considerada um princípio. Todo valor se funda num dever ser, mas este dever ser não é dirigido à vontade de alguém, é um dever ser puro e ideal, conforme explica Hessen:

Dever-ser significa direção para, ou sobre, alguma coisa. Valor significa este alguma coisa, para o qual, ou sobre o qual, se dirige o dever ser, isto é, para que ele tende, ou que ele "intende" $\mathrm{O}$ alvo ou a meta a atingir condicionam a direção, e esta condiciona, por seu lado, o particular modo de ser do alvo ou da meta a atingir. ${ }^{68}$

Segundo Miguel Reale, o pensamento clássico não fez a distinção entre valor e fim. ${ }^{69} \mathrm{O}$ valor é sempre bipolar porque a um valor se contrapõe um desvalor, por exemplo: ao bom se contrapõe o mau; ao belo, o feio; ao nobre, o vil, de forma que o sentido de um exige o do outro. Eles são entidades vetoriais que apontam para um determinado ponto reconhecível como fim. Assim, o "fim é o dever ser do valor reconhecido racionalmente como o motivo do agir" Portanto, tudo aquilo que vale, vale para alguém. ${ }^{70}$ Outros definem a solidariedade como um sentimento, isto é, algo que pertence à ordem da existência, é uma relação concreta entre coisas.

Este tipo conhecimento não se dá pela razão, mas nos é dado pela intuição. Assim, a solidariedade como sentimento está ligada a valores que se aprendem intuitivamente. Segundo Pascal, os sentimentos podem ser negativos ou positivos, mas são apreendidos por meio do espírito da finesse. ${ }^{71}$ Por exemplo, a indiferença consciente é um sentimento negativo (é o desprezo), mas a generosidade é um sentimento positivo. Este raciocínio foi retomado por Adam Smith, no século XVIII, vinte anos antes de escrever a Riqueza da Nação, no livro Teoria dos os sentimentos morais ${ }^{72}$ ele funda a ética no conceito de simpatia. Na introdução desse livro encontramos a seguinte explicação:

A esse princípio da nossa natureza, que nos faz experimentar as situações dos outros, e dividir com eles as paixões que essas situações tendem a despertar, o Sr. Smith dá o nome de simpatia ou solidariedade, palavras que emprega como sinônimos. Reconhece que a simpatia em algumas ocasiões

\footnotetext{
68 HESSEN, Johannes, Filosofia dos valores. São Paulo: Livraria Saraiva, 1946. p.82 e 83.

69 REALE, Miguel. Filosofia do direito. São Paulo: Saraiva, 1998. p. 379.

70 Id. Ibid., p. 189-194.

7 PASCAL, Blaise. Pensamentos. São Paulo: Martins Fontes, 2000. p. 235, item 511 (2). "Existem, pois, duas espécies de espírito, um que penetra forte e profundamente as conseqüencias dos princípios, e é o espírito da justeza. O outro que compreende um grande número de princípios sem os confundir e é o espirito da geometria. Um é a força e a retidão de espírito. Outro é a amplidão do espírito. Ora, um pode muito bem existir sem o outro, podendo o espirito ser forte e estreito, e podendo ser também amplo e fraco."

72 SMITH, Adam. Teoria dos sentimentos morais. São Paulo: Martins Fontes, 1999.
} 
se origina simplesmente da visão de certa emoção em outra pessoa; embora geralmente se deva não tanto à visão da emoção, mas à visão da situação que a provoca. ${ }^{73}$ ( grifos $^{\circ}$ nossos)

Comte- Sponville ${ }^{74}$ aproxima a solidariedade à compaixão ${ }^{75}$ e à simpatia, mas vai além de Smith para explicar que a compaixão significa sofrer com, enquanto simpatia caracteriza-se pelo sentir com. Os sentimentos não representam o destino imodificável, não são deveres que possam ser impostos, mas o ser humano pode ser educado e aprender a senti-los. E Miguel Reale lembra que entre as virtudes teológicas:

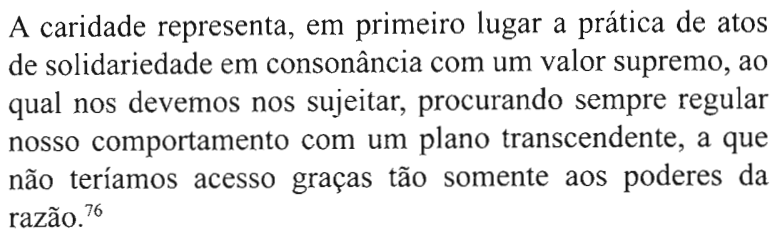

A caridade é uma força que unifica os seres humanos, mas não leva a uma comunidade universal que decorre da unidade do gênero. A Declaração Universal dos Direitos do Homem foi a primeira tentativa de construção de uma comunidade universal ao afirmar "que todos os homens nascem livres e iguais em dignidade e direitos. São dotados de razão e de consciência e devem agir uns para com os outros em espírito de fraternidade. (artigo $1^{\circ}$ )

Após a Revolução Francesa, o recurso à fraternidade serviu para restabelecer a unidade nacional de modo a isolar a moderação do extremismo e não comprometer a dimensão humanística e totalizante da República. Assim afirma-se que a fraternidade é a solidariedade horizontal entre cidadãos livres e iguais. É a manifestação mais completa da virtude como renúncia ao interesse privado. É amizade de todos os cidadãos entre si. A ética revolucionária fez também a ligação entre virtude como sacrifício de si e fraternidade como solidariedade direcionada ao próprio grupo de referência. ${ }^{77}$

Solidariedade, simpatia, compaixão e caridade são conceitos que possuem natureza híbrida, pois são, simultaneamente, sentimentos e virtudes. Se a solidariedade é considerada um sentimento complexo, ela resulta em grande parte do mundo da cultura,

\footnotetext{
Id. Ibid., p.XXV.

COMTE-SPONTEVILLE. André. A compaixão. In: Pequeno Tratado das Grandes Virtudes, p. 115. Id. Ibid., cit., p. 127: "A compaixão, ao contrário, é um sentimento horizontal, só tem sentido entre iguais, ou antes, e melhoir, ela realiza essa igualdade entre aquele que sofre e aquele (ao lado dele e, portanto, no mesmo plano) que compartilha sofrimento. Nesse sentido, não há piedade sem uma parte de desprezo; não há compaixão sem respeito.

76 REALE, Miguel. Variações sobre a caridade. O Estado de São Paulo, São Paulo, 28 nov. 2008, p. A-2.

77 PANELLA, Giuseppe. Fraternité. Semantica di un concetto. Teoria Politica, Milano, anno V, n. 2-3, 1989. p. $143-166$.
} 
que é sempre um mundo solidário, no sentido de interdependência necessária de seus fatores.

Durkheim mostrou que a solidariedade característica das sociedades modernas é a chamada "solidariedade orgânica" ou "solidariedade devida a divisão do trabalho social" em que a coesão social é fundada sobre as diferenças e nas semelhanças que se completam reciprocamente. ${ }^{78}$ Quanto mais os membros de um grupo se distinguem, mais eles são indispensáveis uns aos outros. O fortalecimento da individualidade corresponde exatamente ao fortalecimento da unidade social. Afirma o autor:

[...] se, então, a individualidade do todo cresce ao mesmo tempo que a das partes, a sociedade torna-se mais capaz de se mover com o conjunto, ao mesmo tempo que cada um de seus elementos passa a ter mais movimentos próprios. ${ }^{79}$

Entretanto, também podemos distinguir a solidariedade do mundo animal daquela presente no mundo social. No mundo animal, considera-se que todas as espécies e cada uma delas são solidárias dentro de si mesmas. Os integrantes de um grupo de animais ou de uma espécie determinada vivem nessa relação conjunta de dependência uns em relação a outros, de forma que entre os animais, a solidariedade existe como resultado do seu instinto. ${ }^{80}$

No mundo social, a solidariedade não decorre do instinto, mas de uma ideia racional, segundo a qual a sobrevivência do todo depende da relação de todos os cidadãos entre si ou da sociedade, tomada aqui como o conjunto de cidadãos, com qualquer deles. Celso Lafer vincula a solidariedade à amizade, como condição para a paz universal:

Neste sentido, o espírito de fraternidade consagrado no artigo I da Declaração Universal exprime uma postura que aprofunda a noção clássica da amizade - a de filia - a ela agregando a aspiração da solidariedade horizontal (Panella, 1989, pp. 143-166). Neste sentido o espírito de fraternidade consagrado no artigo I contesta a relação política concebida como uma relação amigo/inimigo e é uma instigação ao "desenvolvimento das relações amistosas entre as nações" ${ }^{81}$

78 FARIAS, José Fernando de Castro. A origem do direito de solidariedade, cit.

79 DURKHEIM, Émile. A divisão do trabalho social. Lisboa: Editorial Presença, 1977. v. 1, p. 153.

80 Para DARWIN, Charles. A origem das espécies. Folha de S.Paulo, São Paulo, 2010, cap. VIII, p. 198: “[...] é infinitamente mais satisfatório considerar certos instintos [...] não como o resultado de atos criadores especiais, mas como pequenas contingências de uma lei geral, tendo por finalidade a conservação de todos os seres organizados, isto é, a sua multiplicação, a sua variação, a sobrevivência do mais forte e a eliminação do mais fraco"

81 LAFER, Celso. A declaração universal dos direitos humanos: sua relevância para a afirmação da tolerância e do pluralismo. In: MARCÍLIO, Maria Luíza (Org.). A declaração universal dos direitos humanos. Sessenta anos: sonhos e realidades. São Paulo: Editora da Universidade de São Paulo, 2008. p. 33. 
A solidariedade horizontal depende da liberdade e da igualdade, seja porque a liberdade é uma condição da igualdade, seja porque só há igualdade onde a liberdade for garantida. ${ }^{82}$ Ainda que não se possa alcançar a solidariedade de um dia para outro, o fato é que nem todos os seres humanos são egoístas e incapazes de sentir compaixão ou empatia pelo outro. A Cruz Vermelha e os Médicos sem Fronteiras são exemplos de solidariedade com valores compartilhados por sociedades diferentes. ${ }^{83}$

No âmbito jurídico a obrigação é solidária (in solido) quando, havendo vários devedores, todos são obrigados à mesma prestação. ${ }^{84} \mathrm{Ou}$ quando cada devedor, isoladamente, deve a totalidade da obrigação. Em ambos os casos, o que importa não é a comunhão de fins, mas o fato de que os devedores estejam obrigados no mesmo grau, de forma que a prestação de um aproveite a todos os outros em face do devedor. ${ }^{85}$ Assim, se não existe entre as obrigações igual graduação ou igual valor não haverá obrigação solidária, apesar da identidade de interesse do credor. Conforme explica Antunes Varela:

Se, apesar disso, falta a solidariedade existir é porque a esta não basta a comunhão de fim da obrigação, embora ela seja necessária; a essa comunhão de fim há de ainda acrescer o facto de os devedores, no sentido do acordo ou da regulamentação legal, estarem obrigados no mesmo grau (auf der gleichen Stufe), por forma que a prestação de um aproveite a todos os outros em face do credor. ${ }^{86}$

Seja como valor ou como sentimento, a ideia de solidariedade atravessou um longo processo histórico-social que culminou com a sua positivação nas ordens jurídicas nacionais e na internacional. ${ }^{87}$

A solidariedade é um princípio jurídico que diz respeito à relação dos integrantes de um conjunto entre si, e da relação do todo com cada uma das suas partes. Este princípio foi integrado à Constituição brasileira em vários dispositivos, de forma que

82 BUNGE, Mario. Filosofía política, solidaridad, cooperación y democracia integral. Barcelona: Editorial Gedisa, 2009. p. 152, afirma que "Hay tres classes de solidaridad: 1 - horizontal o cooperación, así como ayuda mutua entre iguales, 2- o beneficicencia privada y asistencia social estatal a los pobres, 3- Ascendente o bienestar corporativo: los privilegios asignados a los fabricantes de armas y empresas petroleras y farmacéuticas, entre otras, a expensas del contribuyente"

83 BUNGE, Mario. Filosofia política, solidaridad, cooperación y democracia integral, cit. p. 156.

84 VARELA, João de Matos Antunes. Das obrigações em geral. Coimbra: Almedina, 1986. p. 713 . v. 1.

85 FARIAS, José Fernando de Castro. A origem do direito de solidariedade, cit., p. 188, mostra "que os juristas romanos utilizavam a palavra solidariedade para designar o laço que une os devedores de uma soma, de uma divida, cada um sendo responsável pelo todo: era a responsibilidade in solidum, a responsabilidade solidária".

86 VARELA, João de Matos Antunes. Das obrigações em geral, cit., p. 720.

${ }^{87}$ Declaração Universal dos Direitos do Homem. Artigo1 ${ }^{\circ}$ Todos os seres humanos nascem livres e iguais em dignidade e direitos. São dotados de razão e consciência e devem agir em relação uns aos outros com espírito de fraternidade. 
Fábio Konder Comparato afirma ser a solidariedade "o fecho da abóbada do sistema de princípios éticos, pois complementa e aperfeiçoa a liberdade, a igualdade e a segurança" ${ }^{8}$

O princípio da solidariedade mobiliza os indivíduos e os grupos à ação, estimulando-os ao desenvolvimento das relações sociais de forma benéfica. Assim, a noção de hierarquia natural capaz de conter as divergências sociais é substituida pelo dever de solidariedade em busca da unidade dentro da pluralidade. ${ }^{89}$ Bento XVI afirma na Encíclica Caritas in Veritate: ${ }^{90}$

A solidariedade universal é para nós não só um fato e um beneficio, mas também um dever. ${ }^{9 !}$ Hoje muitas pessoas tendem a alimentar a pretensão de que não devem nada a ninguém, a não ser a si mesmas. Considerando-se titulares só de direitos, frequentemente deparam-se com fortes obstáculos para maturar uma responsabilidade no âmbito do desenvolvimento integral próprio e alheio. Por isso é importante invocar uma nova reflexão que faça ver como os direitos pressupõem os deveres, sem os quais seu exercício se transforma em arbítrio. $^{92}$

\section{O dever de solidariedade}

Apesar da polissemia de sentidos, o princípio da solidariedade não se confunde com a compaixão ou com a caridade, porque na sociedade contemporânea ele se constitui como um dever social. Este dever social se traduz nas Constituições modernas, em primeiro lugar, como dever de assistência entre os indivíduos, do Estado e demais organizações numa relação de reciprocidade. No direito brasileiro, a Constituição Federal estabelece:

Art. 195. A seguridade social será financiada por toda a sociedade, de forma direta e indireta, nos termos da lei, mediante recursos provenientes dos orçamentos da União, dos Estados, do Distrito Federal e dos Municípios, e das seguintes contribuições sociais. (grifos nossos)

O poder público é o principal responsável pela organização da seguridade social, ainda que não seja o único obrigado por ela. Conforme a Constituição Federal:

88 COMPARATO, Fabio Konder. Ética. Direito, moral e religião no mundo moderno. São Paulo: Companhia das Letras, p. 577-581.

89 FARIAS, José Fernando de Castro. A origem do direito de solidariedade, cit., p. 194-195.

90 BENTO XVI. Desenvolvimento dos povos, direitos e deveres, ambiente. In: Caritas in Veritate sobre o Desenvolvimento humano integral na caridade e na verdade. Carta Encíclica do Santo Padre, Edições Loyola, Capítulo IV, p. 51.

91 PAULO VI, Carta ec. Populorum progressio, (26/03/1977, 17:AAS 59 (1967) 265-266.

92 Cf. JOÃO PAULO II. Mensagem para o dia mundial da paz, 2003, 5:AAS 95 (2003) 343. 
Art. 194. A seguridade social compreende um conjunto integrado de ações de iniciativa dos Poderes Públicos e da sociedade, destinadas a assegurar os direitos relativos à saúde, à previdência e à assistência social.

Parágrafo único. Compete ao Poder Público, nos termos da lei, organizar a seguridade social, com base nos seguintes objetivos:

I - universalidade da cobertura e do atendimento;

II - uniformidade e equivalência dos benefícios e serviços às populações urbanas e rurais;

III seletividade e distributividade na prestação dos benefícios e serviços;

IV - irredutibilidade do valor dos benefícios;

$\mathrm{V}$ equidade na forma de participação no custeio;

VI - diversidade da base de financiamento;

VII - caráter democrático e descentralizado da administração, mediante gestão quadripartite, com participação dos trabalhadores, dos empregadores, dos aposentados e do Governo nos órgãos colegiados.

Enquanto o dar, o receber e o devolver, que caracterizam a troca mercantil, são obrigações instantâneas, quando elas estão ligadas ao dever de solidariedade passam a obedecer à lógica da necessidade e dos direitos humanos.

No âmbito do Direito Civil, a solidariedade está ligada à ideia de reciprocidade em virtude do vínculo biológico; por exemplo: avós que cuidam dos netos, filhos que se responsabilizam pelos pais, irmãos que assumem a tutela dos que possuem problemas de saúde, etc. ${ }^{93}$ Mas ela pode decorrer da situação social vinculada a um modelo de Estado do Bem-estar Social. Neste caso, a ideia envolve uma pluralidade de instituições em que o compromisso é com a sobrevivência das futuras gerações. Se a reciprocidade ou equivalência das prestações é suficiente no âmbito do direito civil, ela deixa de ser suficiente quando se refere aos direitos ambientais.

Léon Bourgeois iniciou o movimento solidarista na França com a publicação do seu livro Solidarité, no qual considerou a noção de dívida social. Cada indivíduo contrai no momento do nascimento uma dívida com aqueles que o precederam e tornaram a sua existência possível.

A interdependência entre os membros da sociedade industrial complexa baseia-se na teoria de Bourgeois para abranger as gerações anteriores, todos os aspectos da vida e as gerações futuras. Cada geração não é mais que usufrutuária do que tem recebido da anterior e adquire o compromisso de conservar o recebido, incrementando-o e transmitindo-o a novas gerações. O grande mérito da sua teoria foi transformar a

93 Código Civil. "Art. 1.696. O direito à prestação de alimentos é recíproco entre pais e filhos, e extensivo a todos os ascendentes, recaindo a obrigação nos mais próximos em grau, uns em falta de outros" 
solidariedade em um direito exigível. ${ }^{94} \mathrm{O}$ grande problema que se encontra nela é o de determinar quanto devemos e quanto os outros nos devem. Ou seja, quanto uma geração deve para a outra? A ideia de reciprocidade não atende às necessidades de existência. $\mathrm{O}$ dever de solidariedade é muito mais do que uma obrigação de devolver e vai muito além da ideia de reciprocidade. Hans Jonas explica:

A união do poder com a razão traz consigo a responsabilidade, fato que sempre se compreendeu, quando se tratava da esfera das relações intersubjetivas. O que não se compreendera é a nova expansão da responsabilidade sobre a biosfera e a sobrevivência da humanidade, que decorre simplesmente da extensão do poder sobre as coisas e do fato de que este seja, sobretudo um poder destrutivo. O poder e o perigo revelam um dever, o qual por meio da solidariedade imperativa com o resto do mundo animal, se estende do nosso Ser para o conjunto, independentemente do nosso consentimento. ${ }^{95}$

No magnífico trabalho sobre o direito de solidariedade, José Fernando de Castro Farias conclui com acerto que a solidariedade é uma prática que busca a conciliação entre o coletivo e o individual. ${ }^{96} \mathrm{Ou}$ seja, o respeito à liberdade e a igualdade individuais e a efetivação da solidariedade coletiva. Desta forma, a visão filosófica não pode contentarse com os reducionismos do positivismo e do jusnaturalismo do século XIX. Os juristasfilósofos devem propor uma visão dinâmica e integral do direito de solidariedade, segundo a concepção de Gregorio Peces-Barba:

La comprensión de los derechos fundamentales pretende superar estos reduccionismos fundamentalista y funcionalista, y supone una actividade intelectual integradora de lo que llamo Filosofia de los derechos y Derecho Positivo. Es un punto de encuentro entre Derecho y moral, quizás el más relevante de todos, mediado como veremos por el Poder, y que se sitúa en el Derecho en el nivel superior del Ordenamiento y en la moral plantea los problemas centrales. ${ }^{97}$

São Paulo, março de 2010.

94 LOSANO, Mário G. La questione sociale e Il solidarismo francese: attualità d'una Dottrina Antica. Disponível em: <http://www.dircost.unito.it/dizionario/pdf/Losano-Solidarismo.pdf, p.6-7>.

95 JONAS, Hans. O futuro da humanidade e o futuro da natureza. In: O PRINCÍPIO responsabilidade: ensaio de uma ética para a civilização tecnológica, cit., p. 231.

96 FARIAS, José Fernando de Castro. A origem do direito de solidariedade, cit., p. 283: "Se fosse possível resumir em algumas palavras a lógica do Direito de solidariedade, poderíamos dizer que ela representa uma prática juridica que busca a conciliação do coletivo e do individual. Ela representa a tentativa de resolução de um dos problemas fundamentais da sociedade contemporânea: o ajustamento da liberdade do homem à autoridade não mais somente do Estado, mas de todos os grupos sociais aos quais pretence o indivíduo"

97 PECES-BARBA MARTÍNEZ, Gregorio. Lecciones de derechos fundamentales.Con la colaboración de: Rafael de Asís Roig y María del Cármen Barranco Avilés. Madrid: Dykinson, 2004. p. 30-31. 